\title{
Developing School Managers' Change Management Competency in Competency - Based Training Courses in Vietnam
}

\author{
My Giang Son, (Assoc.Prof., PhD) \\ Sai Gon University, Ho Chi Minh City, Vietnam
}

Doi:10.19044/esj.2019.v15n28p15 ～URL:http://dx.doi.org/10.19044/esj.2019.v15n28p15

\begin{abstract}
The change management competency is an important competency of school managers in meeting the requirements of school management in the context of the education innovation in Vietnam. This competency can be formed and developed through educating and training of school managers at all levels. This article presents the concept, structure of the change management competency of school managers and development of the change management competency in competency-based training courses in Vietnam. Given the perspective of competency-based training, this article provides recommendations on developing a change management competency in training courses for school managers.
\end{abstract}

Keywords: Change management competency, Competency-based training

\section{Introduction}

Education managers in general and school managers in particular are important factors contributing to the successful implementation of the education innovation in Vietnam. In order to meet the requirements of school management in the context of the education innovation, these personnel need to have the essential system of school management competencies. In this system, it is inevitable to mention the competency of change management in schools. The change management competency is critical in helping the school principal competently manage schools to successfully perform education innovations; at the same time, it ensures that schools can adapt, exist and develop in accordance with the development trends of the era in particular. The importance of the change management competency of school managers is clearly confirmed in the Regulations on Standards of School Principals (issued in accordance with Circular No. 14/2018/ TT-BGDDT dated July 20, 2018 by Vietnam Ministry of Education and Training). In this document, the issue 
"Innovative Thoughts in Leadership and School Management" becomes an evaluation standard for principals (Standard 1, Criterion 2).

The change management competency of school managers can be formed and developed in many ways such as self-studying and self-training, drawing experience from practical situations of managing changes in schools, participating in training courses on school management, the most important of which is participating in training courses because the knowledge, the skills and the attitudes could be imparted systematically and methodically to the participants. The purpose of the article is to present the concept and structure of the change management competency of school managers; in the meantime, based on the perspective of competency-based training, the article provides some suggestions on developing the change management competency in training courses for school managers.

\section{Content}

\section{The concept of the change management competency of school managers}

According to The Psychology Dictionary edited by Vu (2008), competency refers to "a concept in which people with competencies achieve high performance and quality in the same circumstances for everyone (the operating conditions, the initial knowledge, the experiences...)" (p.499). Nguyen (2014) argued that competency is "the ability to perform responsibly and effectively the actions to solve tasks and problems in the changing situations in the fields of occupations, societies and individuals on the basis of knowledge, skills, techniques, experiences as well as readiness to act" (Nguyen, L., p.5).

Thus, it is possible to generalize that competency is an individual's ability to perform tasks effectively.

According to Nguyen (2018), change management in schools is the combination of the principals' impacts on the change process through the tasks of planning, organizing, leading and inspecting school staffs' performance as well as using all the school resources to achieve the goal of change. This concept shows three important issues: (1) Change management is implemented through the principals' management functions; (2) Change management is to manage all the steps/contents in the process of implementing changes; (3) Change management is the management effects on all the staffs, the financial resources and the facilities of the schools (Nguyen, T.T.D., p.2).

From the foregoing the concept, change management competency of school managers can be defined as the ability of school managers to implement the change management effectively; in other words: 1/ It is the ability to perform management functions (planning, organizing, leading and inspecting) effectively; 2/ It is the ability to manage all the steps/contents in the process of implementing changes effectively; $3 /$ It is the ability to implement 
management effects on all the staffs, the financial resources and the facilities of the schools effectively.

\section{The structure of the change management competency of school managers}

The concepts description given in the preceding section are very essential, in determining the components in the structure of the change management competency of school managers.. Nguyen and My (2018) have proposed the process of managing a specific change in schools to include 11 steps as follows: Analyzing the schools' situations in the field or problem which needs changing; making plans for implementing changes; assigning tasks; raising awareness; improving knowledge and skills; mobilizing the financial resources and facilities for changes; piloting the implementation of changes and drawing from experiences; deploying the implementation of changes in the entire schools; inspecting and evaluating the implementation in the schools; summarizing; reinforcing the results achieved and developing in the following time (Nguyen, T.T.D. \& My, G.S., p.34).

Based on the above process, it is possible to determine that the structure of the change management competency of school managers include 4 basic groups: group of the planning competency, group of the organizing competency, group of leading competency and that of inspecting competency (Table 1).

Table1. The change management competency in schools

\begin{tabular}{|c|c|c|}
\hline No & Groups & Competency Components \\
\hline \multirow{2}{*}{1} & \multirow{2}{*}{$\begin{array}{l}\text { Planning } \\
\text { competency }\end{array}$} & Competency to analyze the situations \\
\hline & & Competency to build appropriate plans for practical conditions \\
\hline 2 & $\begin{array}{l}\text { Organizing } \\
\text { competency }\end{array}$ & $\begin{array}{l}\text { Competency to assign tasks and establish the relationships between } \\
\text { departments and individuals in the implementation process }\end{array}$ \\
\hline \multirow{5}{*}{3} & \multirow{5}{*}{$\begin{array}{l}\text { Leading } \\
\text { competency }\end{array}$} & $\begin{array}{l}\text { Competency to raise awareness and create motivation to } \\
\text { implement changes }\end{array}$ \\
\hline & & $\begin{array}{l}\text { Competency to improve knowledge and skills to implement } \\
\text { changes }\end{array}$ \\
\hline & & $\begin{array}{l}\text { Competency to mobilize the financial resources and facilities for } \\
\text { changes }\end{array}$ \\
\hline & & $\begin{array}{l}\text { Competency to pilot the implementation of changes and draw from } \\
\text { experiences }\end{array}$ \\
\hline & & $\begin{array}{l}\text { Competency to deploy the implementation of changes in the entire } \\
\text { schools }\end{array}$ \\
\hline \multirow{2}{*}{4} & \multirow{2}{*}{$\begin{array}{l}\text { Inspecting } \\
\text { competency }\end{array}$} & Competency to inspect and evaluate the implementation \\
\hline & & Competencyto summarize the implementation process \\
\hline
\end{tabular}




\section{Developing the change management competency for school managers Overview of the competency-based educating and training}

Competency-based Education "emphasizes the outcome of learners. A learner is assessed as meeting the requirements of completing the subjects, programs, courses or levels when demonstrating the achievement and application of knowledge, skills, attitudes, values and behaviors based on the proposed competency criteria" (Vietnam Ministry of Education and Training, ETEP Program Management Unit, 2018). According to this approach, the concern is not that a learner "learns something", but that he/she "applies what is learned to perform something". Therefore, according to Nguyen (2016), it is important to "teach how to learn and how to apply knowledge, skills and attitudes to solve problems related to reality and then form competency" (Nguyen, Q.T., p.68-82).

Thus, the competency-based educating and training is actually an approach focusing on the outcome of the educating and training process, which emphasizes which competencies need to be achieved upon course completion. To do so, first of all, it is very important to determine the competency outcome standards associated with the professional requirements; then, choose the styles, the ways, the contents of competency development and the methods of competency assessment during educating and training process.

\section{Developing the change management competency in the competency-based educating and training}

Based upon the opinions on competency-based educating and training, developing the change management competency in educating and training courses for school managers can be conducted as follows:

A) Take the subject/thematic "Change management in Education" into the educating and training programs

This article refers to the Master of Education Management program and short courses for training school managers.

The Master of Education Management program: This program is available in many educational institutions in Vietnam, mainly for educational managers and school managers at all levels. In recent years, most educational institutions have taken the subject "Change management in Education" into the training programs.

Short courses for school managers: These courses are implemented at most educational institutions assigned to train educational managers of all levels in Vietnam - from the central levels to the local ones. They are held in short periods of time, which may be weeks, months with the flexible organization time such as during the school year or in the summer time. Training programs in these courses are varied and can be designed by each 
educational institution. However, there are two important types of programs for school managers issued by Vietnam Ministry of Education and Training: The program for school principals in the form of Vietnam - Singapore transnational education (issued under Decision No.3502/ QD-BGDDT dated May 14, 2009 by Vietnam Ministry of Education and Training) and The Program for high school managers (issued under Decision No.382/ QDBGDDT dated January 20, 2012 by Vietnam Ministry of Education and Training). Importantly, both programs spare 15 periods for the thematic "Change management in Education".

In order to educate and train educational managers to meet the requirements of school management in the context of education innovations, in the coming time, educational institutions should continue holding the subject/thematic in high esteem in their educating and training programs.

B) Teaching the subject/thematic "Change management in Education" in the competency-based approach

a. Outcome standards of the subject/thematic: Identify the outcome standards of knowledge, skills and specific attitudes so as to form and develop the competency of change management for learners with the 4 groups of components in the structure of change management competency.

b. Contents of the subject/thematic: Design the contents closely related to the competency components identified in the 4 groups of the change management competency of school managers.

c. Methods and forms of teaching the subject/thematic: In competencybased teaching, teachers only play a role of designing and guiding the teaching contents, and learners must build up their knowledge, skills, and attitudes through exploration, discovery and creativity.

Teaching the subject/thematic "Change management" also follows the above principles. The teaching methods can be used such as group discussions, case studies, presentations, role plays,...

Organize for learners group-based learning, individual-based learning, and self- directed learning...

Organize for learners to study projects and learn from the specific jobs related to managing changes in schools, such as:

i. Practise making the comprehensive analysis of the school situations (both inside and outside the schools) and predict changes occurring in the schools for a period of 1 year, 3 years or 5 years...;

ii. Practise making the school innovation projects/plans of strategies for school development (within 3 years/5 years,...);

iii. Practise making a plan to implement a specific change in the schools;

iv. Map the organizational structures of human resources to implement a specific change in the schools; 
v. Make a speech on motivating and inspiring the school staffs to unanimously implement a specific change;

vi. Practise planning the theoretical training courses for teachers to implement a specific innovation;

vii. Practise making a plan to mobilize finance, facilities, equipments and devices to implement a specific change in the schools;

viii. Make a speech at the parents' meeting to propagate and advocate supporting the implementation of a specific change in the schools;

ix. Develop the scenarios and perform to illustrate a meeting to draw experience on the piloting implementation of a specific change in the schools;

$x$. Create the situations and perform to illustrate how to solve the situations that arise in the process of managing changes in the schools;

xi. Practise writing preliminary/summarizing reports on the implementation of a specific change in the schools; etc.

d. Assessment of the learning results:

- Types of assessment: In competency-based teaching, the assessment of learning results plays an important role, helping teachers and learners to know the levels of competency achieved in learners, then teachers and learners can have reasonable adjustments and additions to the contents and the additional practising time. Therefore, the assessment is conducted not only in the final results but also in the learning process. The assessment of the subject/thematic "Change management" will also include two types: the formative assessment and the summative assessment.

- Contents and assessment criteria: The contents of assessment are the specific competencies described in the outcome standards of the subject/thematic. Assessment criteria should be developed by teachers and clearly implemented for learners. These criteria can focus both on the implementation process (attitudes, levels of participation, cooperation, thoughts, methods of implementation...) and on the achieved products (e.g. projects/plans, organizational structure diagrams, speeches, meeting scripts, reports, etc.).

\section{Conclusion}

The change management competency is a necessary competency to help school managers to manage schools in the context of education innovation in Vietnam. This competency can be formed and developed for school managers in the educating and training courses on school management. The educating and training programs need to spare a certain amount of time for the subjecton change management. Analyses of the concept and structure of the change management competency allow designing outcome standards of the subject, then it is possible to select the contents, methods, forms, and means of 
assessment in order to form and develop the change management competency for school managers.

\section{References:}

1. Nguyen, L. (2014). Competency framework of high school principals (High School Education Development Project, Phase 2), Hanoi.

2. Nguyen, Q. T. (2016). Competency - based assessmemnt. VNU Journal of Science, Education Research, 32 (2), 68 - 82.

3. Nguyen, T. T. D. (2018). Change management process in schools. Vietnam Journal of Educational Sciences, 7, 1 - 6 .

4. Nguyen, T. T. D., \& My, G. S. (2018). Change management in schools - Theoretical and Practical issues. Ho Chi Minh City: Vietnam Education Publishing House.

5. Vietnam Ministry of Education and Training. (2018). Regulations on Standards of School Principals (issued in accordance with Circular No. 14/2018/ TT-BGDDT dated July 20, 2018 by the Minister of Education and Training).

6. Vietnam Ministry of Education and Training, ETEP Program Management Unit. (January 17, 2018). Advantages of Competencybased Education, Retrieved from etep.moet.gov.vn (June 26, 2019).

7. Vu, D. (2008). Psychology dictionary. Hanoi: Encyclopedia Publishing House. 